\title{
SUSU FERMENTASI DENGAN BIJI NANGKA SEBAGAI PREBIOTIK
}

\author{
[Fermented Milk with Jackfruit Seeds as Prebiotic]
}

\author{
Winiati P. Rahayu ${ }^{1,2) \star}$, Suliantari ${ }^{1,2)}$, Umi Kartika Safitri ${ }^{1)}$, dan Wibisono Adhi ${ }^{1)}$ \\ 1) Departemen IImu dan Teknologi Pangan, Fakultas Teknologi Pertanian, IPB University, Bogor \\ 2) Southeast Asian Food and Agricultural Science and Technology (SEAFAST) Center, IPB University, Bogor
}

Diterima 17 April 2020 / Disetujui 7 Desember 2020

\begin{abstract}
Jackfruit seeds (Artocarpus heterophyllus Lam.) contain dietary fiber, thus it is potential as prebiotic to be used in fermented milk drink. This research aimed to obtain the fermented milk composition made from fresh milk and jackfruit seed flour containing active lactic acid bacteria ( $L A B)$, preferred hedonic level and to identify the chemical properties of the resulting fermented milk. Variables of this research were the jackfruit seed flour concentrations of 4, 5, 6\% (w/V) and two LAB used (Lactobacillus plantarum and Lactobacillus brevis). The composition was selected based on the viable number of $L A B, p H$ value, and sensory quality. The selected composition was the fermented milk made of fresh milk and $4 \%(\mathrm{~W} / \mathrm{V})$ jackfruit seed flour and L. brevis. The viable number of $L A B$ of the fermented milk was $10.59 \log C F U / \mathrm{mL}$. The sensory quality of the fermented milk was neutral until rather preferred for color, flavor, taste, texture, and overall. The chemical contents $(\% \mathrm{~b} / \mathrm{b})$ of product was $78.16 \%$ of moisture content, $2.34 \%$ of ash content, $2.85 \%$ of fat content, $3.15 \%$ of protein content, $13.51 \%$ of carbohydrate content, and $1.73 \%$ of lactic acid content.
\end{abstract}

Keywords: fermented milk, jackfruit seed, lactic acid bacteria

\section{ABSTRAK}

Biji nangka (Artocarpus heterophyllus Lam.) mengandung serat pangan sehingga berpotensi sebagai prebiotik yang dapat ditambahkan dalam pembuatan minuman susu fermentasi. Tujuan penelitian ini adalah memperoleh komposisi minuman susu fermentasi dengan bahan dasar tepung biji nangka dengan penambahan bakteri asam laktat (BAL) yang aktif, mengukur tingkat kesukaan yang dapat diterima, dan untuk mengetahui mutu kimianya. Perlakuan yang diteliti adalah pengaruh jumlah tepung biji nangka $(4,5$, dan $6 \%(\mathrm{~b} / \mathrm{v})$ ), dan dua jenis BAL (Lactobacillus plantarum dan Lactobacillus brevis) pada pembuatan susu fermentasi. Pemilihan komposisi bahan dilakukan berdasarkan analisis total BAL, nilai $\mathrm{pH}$, dan mutu sensori. Komposisi bahan yang terpilih dari penelitian ini adalah penggunaan susu sapi yang ditambah dengan tepung biji nangka $4 \%(\mathrm{~b} / \mathrm{v})$ dengan starter $L$. brevis. Total BAL pada susu fermentasi yang dihasilkan adalah 10,59 log CFU/mL. Mutu sensori untuk atribut warna, aroma, rasa, tekstur, dan overall adalah netral hingga agak disukai. Susu fermentasi yang dibuat dengan komposisi bahan tersebut mempunyai kadar air sebesar 78,16\%, kadar abu sebesar 2,34\%, kadar lemak sebesar 2,85\%, kadar protein sebesar $3,15 \%$, kadar karbohidrat sebesar $13,51 \%$, dan kadar asam laktat sebesar $1,73 \%$.

Kata kunci: bakteri asam laktat, susu fermentasi, tepung biji nangka

\section{PENDAHULUAN}

Gangguan pencernaan dapat terjadi karena ketidakseimbangan mikroflora usus. Ketidakseimbangan dalam komposisi mikrobiota usus dapat dikaitkan dengan terjadinya penyakit kronis atau yang berhubungan dengan gaya hidup seperti penyakit radang usus, obesitas, dan diabetes tipe 2 serta dengan penyakit autoimun tertentu seperti diabetes

\footnotetext{
*Penulis Korespondensi:
}

E-mail: wpr@apps.ipb.ac.id tipe 1, atau alergi asma (Hooper et al., 2012). Gangguan pencernaan merupakan salah satu penyakit yang dapat menyebabkan kematian. Di Indonesia, pada tahun 2017 insiden diare semua umur secara nasional adalah 270/1.000 penduduk dengan tingkat kematian sebesar 1,97\% (Kementerian Kesehatan Republik Indonesia, 2018). Fenomena tersebut memengaruhi pola pikir masyarakat dalam memilih konsumsi pangan untuk menjaga kesehatan saluran pencernaan. Masyarakat tidak hanya menginginkan pangan yang menarik secara sensori dan berguna untuk pemenuhan zat gizi tubuh, tetapi juga me- 
merlukan pangan yang bermanfaat bagi kesehatan atau dikenal sebagai pangan fungsional (Das et al., 2012).

Fermentasi merupakan proses pemecahan senyawa organik menjadi senyawa sederhana seperti asam lemak rantai pendek (short chain fatty acid/SCFA), asam lemak rantai cabang (branched chain fatty acid/BCFA), amonia, amina, senyawa fenolik dan gas termasuk hidrogen, metana dan hidrogen sulfida yang melibatkan aktivitas mikroba atau campuran beberapa spesies mikroba (Verbeke et al., 2015). Salah satu produk fermentasi yang sudah dikenal masyarakat adalah minuman susu fermentasi. Fermentasi susu dapat menghambat pertumbuhan mikroba patogen dan mikroba perusak susu sehingga dapat memperpanjang masa simpan susu, selain rasa dan aroma susu fermentasi yang disukai. Keuntungan lainnya penggunaan mikroba untuk fermentasi adalah sifat probiotiknya. Mikroba yang diisolasi dari susu kambing seperti Lactobacillus. rhamnosus dan Lactobacillus plantarum bersifat probiotik (Setyawardani et al., 2011). Bakteri asam laktat tersebut mampu menghambat pertumbuhan Salmonella Typhimurium, Escherichia coli, Bacillus cereus dan Pseudomonas aeruginosa secara in vitro (Setyawardani et al., 2014) dan meningkatkan jumlah sel limfosit selama 10 hari infeksi Salmonella typhimurium dan setelahnya (Setyawardani et al., 2017).

Pembuatan minuman susu fermentasi dapat dikembangkan dengan penambahan prebiotik untuk meningkatkan nilai fungsionalnya. Prebiotik merangsang pertumbuhan atau aktivitas spesies mikroba spesifik dalam mikrobiota usus untuk memberi manfaat kesehatan (Martinez, 2014).

Panel ahli pada International Scientific Association for Probiotics and Prebiotics (ISAPP) pada tahun 2016 merumuskan definisi prebiotik sebagai substrat yang digunakan secara selektif oleh mikroorganisme inang yang memberikan manfaat kesehatan. Selektivitas dianggap sebagai inti dari konsep prebiotik (Gibson et al., 2017). Berbeda dengan serat, seperti selulosa, pektin, dan xilan, yang mendorong pertumbuhan banyak mikroorganisme usus, prebiotik seperti frukto-oligosakarida dan galaktooligosakarida terutama merangsang proliferasi Lactobacillus dan Bifidobacterium (Quigley, 2019). Probiotik adalah mikroorganisme hidup yang bila diberikan dalam jumlah yang cukup dapat memberikan manfaat kesehatan pada tubuh inang. Pada tahun 2014, ISPP mengategorikan empat kelompok produk yang berisi mikroorganisme hidup untuk dikonsumsi manusia yakni kelompok kultur hidup dan aktif, probiotik dalam pangan dan suplemen dengan klaim kesehatan, probiotik dalam pangan dan suplemen dengan klaim kesehatan spesifik, dan obat probiotik (Hill et al., 2014). Biji nangka dapat menjadi salah satu bahan lokal berpotensi sebagai prebiotik, sehingga dapat diaplikasikan dalam pembuatan minuman susu fermentasi. Dalam penelitian ini, substrat tepung biji nangka (TBN) digunakan untuk mendukung pertumbuhan Lactobacillus plantarum dan Lactobacillus brevis. Kedua bakteri ini telah diketahui bermanfaat untuk kesehatan karena meningkatkan kesehatan usus dan merangsang fungsi kekebalan, meningkatkan aktivitas beberapa enzim, dan meningkatkan kapasitas antioksidan produk akhir (Shen et al., 2014; Talpur et al., 2013; Ramos et al., 2013; Yakabe et al., 2009).

Biji nangka termasuk bahan pangan yang belum banyak dimanfaatkan oleh masyarakat karena selama ini hanya dianggap sebagai limbah. Pemanfaatan biji nangka sebagai bahan baku pembuatan produk susu fermentasi dapat memberikan nilai tambah pada biji nangka. Tepung biji tanaman yang salah satunya TBN dapat digunakan sebagai media pertumbuhan bakteri Lactobacillus lactic (Pathak dan Martirosyan, 2012). Menurut Wichienchot et al. (2011), alasan biji nangka mampu menstimulus pertumbuhan bakteri Lactobacillus adalah karena mengandung 403,44 mg/g (bk) polisakarida dan $29,35 \mathrm{mg} / \mathrm{g}$ oligosakarida (bk) yang tidak dapat dicerna oleh enzim pencernaan serta bersifat selektif dalam fermentasi mikroflora pada uji in vitro menggunakan usus buatan. Tepung biji nangka juga memiliki kemampuan menyerap air yang sangat tinggi. Tepung biji nangka memiliki struktur matriks protein yang bersifat hidrofobik sehingga memiliki foam capacity dan foam stability yang baik, dan sifat ini mendukung proses pembuatan minuman kesehatan (Chowdhury et al., 2012)

Tujuan dari penelitian ini adalah untuk mendapatkan komposisi terbaik dari formulasi susu sapi, TBN dan mikroba BAL untuk pembuatan minuman susu fermentasi. Pengukuran didasarkan pada mutu sensori dan mutu kimia produk minuman susu fermentasi. Diharapkan penelitian ini dapat memberikan alternatif produk pangan fungsional bagi masyarakat untuk meningkatkan kesehatan dengan menggunakan sumber daya lokal.

\section{BAHAN DAN METODE}

\section{Bahan}

Bahan-bahan yang digunakan adalah susu sapi segar dari Fakultas Peternakan IPB, susu skim, biji nangka dari campuran varietas Salak dan Bubur, akuades, gula pasir, kultur BAL dari Laboratorium Mikrobiologi LIPI Cibinong (Lactobacillus plantarum BTTC B-649 dan Lactobacillus brevis BTCC B-645). Media yang digunakan untuk pertumbuhan BAL yaitu de Man Rogosa Sharp Broth (MRSB) (Oxoid) dan de Man Rogosa Sharp Agar (MRSA) (Oxoid). Pereaksi yang digunakan untuk uji $\mathrm{pH}$ adalah bufer fosfat $\mathrm{pH} 4$ dan 7; pereaksi yang digunakan untuk uji 
total asam tertitrasi adalah indikator fenoftalein dan $\mathrm{NaOH} 0,1 \mathrm{~N}$; pereaksi untuk analisis kadar protein adalah $\mathrm{K}_{2} \mathrm{SO}_{4}, \mathrm{HgO}, \mathrm{H}_{2} \mathrm{SO}_{4}$ pekat, etanol, $60 \%$ $\mathrm{NaOH}-5 \% \quad \mathrm{Na}_{2} \mathrm{~S}_{2} \mathrm{O}_{3} .5 \mathrm{H}_{2} \mathrm{O}$, asam borat, indikator metilen red metilen blue (MRMB), $\mathrm{HCl} \mathrm{0,02} \mathrm{N,} \mathrm{Tris-}$ $\mathrm{HCl}$, serta pereaksi yang digunakan untuk analisis kadar lemak adalah $\mathrm{HCl} 25 \%$ dan heksana. Bahan kimia tersebut berasal dari Merck (Jerman) yang diperoleh dari stock room Departemen IImu dan Teknologi Pangan IPB.

\section{Metode}

Tahapan penelitian meliputi pembuatan tepung biji nangka (TBN), pembuatan kultur starter, penentuan komposisi susu, penambahan tepung biji nangka dan penambahan starter. Analisis yang dilakukan meliputi analisis jumlah BAL, analisis sensori, dan analisis kimia.

\section{Pembuatan tepung biji nangka (Chowdhury et al., 2012)}

Pembuatan tepung biji nangka (TBN) dilakukan dengan tahapan sebagai berikut ini. Pencucian biji nangka dilakukan untuk menghilangkan kotoran, diikuti dengan perebusan pada suhu $90^{\circ} \mathrm{C}$ selama 10 menit menggunakan steam jacket cattle (Armfield, Inggris) untuk menghilangkan lendir dan mempermudah pelepasan kulit biji nangka. Tahap berikutnya dilakukan pemisahan kulit menggunakan abrassive peeler (Armfield, Inggris), pengirisan menggunakan slicer (Hallde, Swedia) dengan ketebalan \pm 2 $\mathrm{mm}$ untuk memudahkan proses pengeringan. $\mathrm{Pe}-$ ngeringan dilakukan pada suhu $60^{\circ} \mathrm{C}$ selama 4 jam menggunakan cabinet drier (Armfield, Inggris) untuk mengurangi kadar air biji nangka, diikuti dengan penggilingan menggunakan disc mill (Armfield, Inggris) dengan ukuran 60 mesh, dan pengayakan menggunakan ayakan bergoyang ukuran 100 mesh agar tekstur tepung halus dan tekstur produk akhir tidak berpasir. Rendemen yang diperoleh dari proses pembuatan TBN sebesar $9,66 \%$.

\section{Pembuatan kultur starter BAL (Rahayu et al., 2011)}

Kultur starter dibuat dengan modifikasi metode Rahayu et al. (2011) pada tahap penggunaan susu steril, jumlah inokulum BAL, dan waktu inkubasi. Kultur BAL Lactobacillus plantarum dan Lactobacillus brevis diambil dari kultur stok MRSA (Oxoid) chalk semi solid dengan menggunakan jarum ose. Kemudian jarum ose dicelupkan ke dalam media MRSB. Kultur BAL di dalam MRSB diinkubasi pada suhu $37^{\circ} \mathrm{C}$ selama 24 jam. Sebanyak $2 \%$ (v/v) kultur BAL dalam MRSB ditambahkan ke dalam larutan susu skim $12 \%(b / v)$ yang sebelumnya telah dipanaskan pada suhu $100^{\circ} \mathrm{C}$ selama 30 menit, kemudian diinkubasi pada suhu $37^{\circ} \mathrm{C}$ selama 24 jam.

\section{Pemilihan komposisi produk (modifikasi metode Lee dan Lucey, 2010) \\ Penelitian ini menggunakan 12 komposisi} (Tabel 1) dengan 2 kali ulangan. Perlakuan persentase tepung biji nangka (TBN) ditambahkan sebanyak $0,4,5$, dan $6 \%(\mathrm{~b} / \mathrm{v})$ dan jenis BAL (Lactobacillus plantarum, Lactobacillus brevis, dan campuran keduanya). Komposisi tanpa TBN digunakan sebagai kontrol.

Persentase TBN 4-6\% (b/v) merupakan tiga persentase terbesar yang dapat ditambahkan dalam komposisi bahan baku pembuatan susu fermentasi. Penambahan TBN sebesar lebih dari 6\% menyebabkan gelatinisasi yang mengakibatkan terbentuknya gel setelah didinginkan. Proses pembuatan minuman susu fermentasi dilakukan dengan modifikasi metode Lee dan Lucey (2010) pada tahap penambahan bahan baku, homogenisasi, suhu pendinginan setelah homogenisasi, dan inkubasi.

Tabel 1. Total BAL dan nilai $\mathrm{pH}$ minuman susu fermentasi

\begin{tabular}{clcc}
\hline No. & \multicolumn{1}{c}{ BAL dan Konsentrasi TBN } & Total BAL $(\log$ CFU/mL) & $\mathrm{pH}$ \\
\hline 1 & L. plantarum, TBN 0\% (b/v) & $9,85 \pm 0,10^{\mathrm{b}}$ & $4,77 \pm 0,05^{\mathrm{b}}$ \\
2 & L. plantarum, TBN 4\% (b/v) & $10,51 \pm 0,02^{\mathrm{a}}$ & $4,08 \pm 0,04^{\mathrm{a}}$ \\
3 & L. plantarum, TBN 5\% (b/v) & $10,51 \pm 0,24^{\mathrm{a}}$ & $4,03 \pm 0,04^{\mathrm{a}}$ \\
4 & L. plantarum, TBN 6\% (b/v) & $10,52 \pm 0,15 \mathrm{a}$ & $4,02 \pm 0,04^{\mathrm{a}}$ \\
5 & L. brevis, TBN 0\% (b/v) & $9,64 \pm 0,38^{\mathrm{a}}$ & $4,72 \pm 0,12^{\mathrm{b}}$ \\
6 & L. brevis, TBN 4\% (b/v) & $10,59 \pm 0,30^{\mathrm{a}}$ & $4,15 \pm 0,06^{\mathrm{a}}$ \\
7 & L. brevis, TBN 5\% (b/v) & $10,68 \pm 0,06^{\mathrm{a}}$ & $4,08 \pm 0,01^{\mathrm{a}}$ \\
8 & L. brevis, TBN 6\% (b/v) & $10,52 \pm 0,05^{\mathrm{a}}$ & $4,03 \pm 0,04^{\mathrm{a}}$ \\
9 & L. plantarum dan L. brevis, TBN 0\% (b/v) & $9,84 \pm 0,05^{\mathrm{b}}$ & $4,67 \pm 0,06^{\mathrm{b}}$ \\
10 & L. plantarum dan L. brevis, TBN 4\% (b/v) & $10,32 \pm 0,28^{\mathrm{a}}$ & $4,10 \pm 0,01^{\mathrm{a}}$ \\
11 & L. plantarum dan L. brevis, TBN 5\% (b/v) & $10,52 \pm 0,09^{\mathrm{a}}$ & $4,09 \pm 0,06^{\mathrm{a}}$ \\
12 & L. plantarum dan L. brevis, TBN 6\% (b/v) & $10,46 \pm 0,23^{\mathrm{a}}$ & $4,06 \pm 0,02^{\mathrm{a}}$ \\
\hline Keterangan. Data &
\end{tabular}

Keterangan: ${ }^{a}$ Data yang diikuti huruf sama pada kolom sama tidak berbeda nyata pada uji Duncan taraf 0,05 
Pembuatan minuman susu fermentasi ini diawali dengan pencampuran susu sapi segar $500 \mathrm{~mL}$ $(100 \%(\mathrm{v} / \mathrm{v}))$, tepung biji nangka $(0,4,5,6 \%(\mathrm{~b} / \mathrm{v}))$, dan gula pasir $(5 \%(\mathrm{~b} / \mathrm{v}))$. Selanjutnya dilakukan pasteurisasi pada suhu $80-85^{\circ} \mathrm{C}$ selama 30 menit. Pasteurisasi bertujuan membunuh mikroba yang tidak diinginkan sehingga memperkecil kompetisi kultur starter dan mengurangi oksigen terlarut yang dapat mengganggu pertumbuhan kultur starter (Lee dan Lucey, 2010). Susu pasteurisasi tersebut didinginkan hingga suhu $\pm 37^{\circ} \mathrm{C}$ dan kemudian dilakukan inokulasi kultur starter.

Persentase kultur starter yang ditambahkan masing-masing sebanyak $2 \%(\mathrm{~b} / \mathrm{v})$ untuk kultur tunggal dan masing-masing $1 \%$ (b/v) untuk kultur campuran dengan jumlah BAL $10^{7} \mathrm{CFU} / \mathrm{mL}$. Persentase kultur starter yang ditambahkan sesuai dengan Aswal et al. (2013) yang menyatakan bahwa jumlah kultur starter yang umumnya ditambahkan dalam pembuatan susu fermentasi adalah 2-4\%. Jumlah $\mathrm{BAL} 10^{7} \mathrm{CFU} / \mathrm{mL}$ telah sesuai dengan syarat minimal bakteri starter menurut SNI 2981-2009 tentang susu fermentasi (BSN, 2009). Setelah inokulasi, inkubasi dilakukan pada suhu $37^{\circ} \mathrm{C}$ selama 18 jam. Langkah terakhir yang dilakukan adalah menyimpan minuman susu fermentasi pada suhu $4^{\circ} \mathrm{C}$ menunggu saat analisis.

\section{Pemilihan komposisi}

Pada tahap pemilihan formulasi susu fermentasi, analisis dilakukan terhadap 12 perlakuan (Tabel 1) yang meliputi analisis total BAL dengan metode hitungan cawan (BAM, 2001) dan analisis pH (AOAC, 2000). Kedua analisis tersebut dilakukan secara duplo. Setelah itu, dilakukan analisis sensori terhadap formulasi yang memiliki total BAL yang tinggi dan memenuhi standar $\mathrm{pH}$ yaitu 4,0-4,5. Analisis sensori yang dilakukan adalah uji rating hedonik oleh 70 orang panelis terhadap atribut warna, aroma, rasa, tekstur dan overall (keseluruhan). Skala penilaian yang digunakan adalah 7 skala, yaitu 1 (sangat tidak suka), 2 (tidak suka), 3 (agak tidak suka), 4 (netral), 5 (agak suka), 6 (suka), dan 7 (sangat suka). Selain itu, panelis juga diminta untuk mengurutkan empat atribut sensori (warna, aroma, rasa, dan tekstur) berdasarkan besarnya pengaruh atribut tersebut terhadap produk. Tahap selanjutnya, formulasi yang memiliki tingkat kesukaan tertinggi pada analisis sensori dianalisis mutu kimianya secara duplo, meliputi kadar air, kadar abu, kadar lemak, kadar protein, total asam tertitrasi, $\mathrm{pH}$ (AOAC, 2000), dan karbohidrat (Andarwulan et al. 2011).

Rancangan percobaan yang digunakan pada penelitian ini adalah rancangan acak lengkap faktorial dengan dua kali ulangan. Data analisis total $\mathrm{BAL}, \mathrm{pH}$, sensori, dan mutu kimia dianalisis menggunakan analysis of variance (ANOVA). Jika hasil uji menggunakan ANOVA menyatakan bahwa terdapat signifikansi perbedaan pada taraf 0,05 , maka uji tersebut dilanjutkan dengan uji Duncan. Data-data tersebut diuji secara statistik menggunakan SAS 9.1. Model matematika yang digunakan berdasarkan Matjik dan Sumartajaya (2011).

\section{HASIL DAN PEMBAHASAN}

\section{Total BAL dan $\mathrm{pH}$ pada minuman susu fermen- tasi}

Hasil analisis terhadap total BAL dan nilai $\mathrm{pH}$ pada produk akhir tertera pada Tabel 1. Tabel 1 menjelaskan bahwa total BAL dan pH kontrol (perlakuan yang tidak ditambah tepung biji nangka (TBN) berbeda nyata dengan perlakuan yang ditambah TBN, tetapi penambahan TBN dengan jumlah 4,5 , dan $6 \%(\mathrm{~b} / \mathrm{v})$ tidak berbeda nyata. Hal tersebut menunjukkan bahwa penambahan TBN pada pembuatan minuman susu fermentasi mampu meningkatkan jumlah BAL dan menurunkan nilai $\mathrm{pH}$ pada produk akhir baik pada jenis bakteri $L$. plantarum, L. brevis maupun campuran keduanya. Total BAL pada kontrol untuk ketiga variasi bakteri berkisar $10^{9} \mathrm{CFU} / \mathrm{mL}$, sedangkan total BAL susu fermentasi dengan TBN adalah $10^{10} \mathrm{CFU} / \mathrm{mL}$. Hal ini menunjukkan ada pertumbuhan BAL yang baik pada media yang diberi tambahan TBN dan telah memenuhi standar minimal untuk jumlah kultur probiotik yang harus ada pada pangan. WHO/FAO (2006) menetapkan jumlah mikroba probiotik yang bermanfaat bagi kesehatan inang bila jumlahnya sebanyak $10^{6}-10^{8} \mathrm{CFU} / \mathrm{mL}$.

Minuman susu fermentasi dengan penambahan TBN memiliki total BAL satu log lebih besar dibandingkan dengan yang tidak ditambah TBN, artinya, TBN mampu meningkatkan total BAL. Peningkatan total BAL tersebut karena adanya tambahan nutrisi seperti protein, lemak, dan serat pangan yang terkandung pada TBN. Serat pangan terdiri dari jenis karbohidrat yang tidak dapat dicerna oleh enzim pencernaan tetapi dapat difermentasi oleh mikroflora kolon. Bakteri mampu memanfaatkan protein, lemak, dan karbohidrat dalam susu untuk pertumbuhan dan metabolisme (Verbeke et al., 2015).

Nilai $\mathrm{pH}$ pada kontrol untuk ketiga variasi bakteri lebih tinggi daripada formula dengan penambahan TBN. Kontrol memiliki pH berkisar antara 4,7-4,8, sedangkan nilai $\mathrm{pH}$ pada minuman susu fermentasi dengan penambahan TBN berkisar antara 4,0-4,2. Penurunan $\mathrm{pH}$ pada produk dengan penambahan TBN tersebut sejalan dengan hasil analisis total BAL. Aktivitas BAL dalam menghasilkan asam organik lebih tinggi pada susu fermentasi dengan penambahan TBN dibandingkan dengan kontrol karena nutrisi yang tersedia juga lebih banyak. Jenis asam organik yang menyebabkan terjadinya penurunan $\mathrm{pH}$ ditentukan oleh karakteristik dari BAL yang 
digunakan untuk fermentasi. Bakteri L. plantarum merupakan BAL homofermentatif yang menghasilkan asam laktat, sedangkan bakteri $L$. brevis merupakan tipe BAL heterofermentatif yang menghasilkan asam laktat, asam asetat, dan $\mathrm{CO}_{2}$ (Prückler et al., 2015). Penurunan $\mathrm{pH}$ terjadi tidak hanya disebabkan karena asam yang dihasilkan oleh BAL, tetapi juga karena pembentukan asam lemak rantai pendek seperti asam asetat, propionat, dan butirat.

Nilai $\mathrm{pH}$ pada minuman susu fermentasi ini selaras dengan standar $\mathrm{pH}$ susu fermentasi secara umum yang juga diaplikasikan untuk yoghurt dan kefir, yaitu 4,0-4,5 (Lee et al., 2020). Nilai pH merupakan salah satu parameter keamanan pada produk minuman susu fermentasi. Listeria monocytogenes mati dengan cepat pada susu fermentasi dengan pH kurang dari 4,2 (Caleja et al., 2016). Yoghurt dengan $\mathrm{pH}$ lebih dari 4,5 dapat ditumbuhi Salmonella pada penyimpanan selama 10 hari atau Escherichia coli 0157 pada penyimpanan selama 7 hari. Bakteri asam laktat dalam proses metabolismenya selain menghasilkan asam laktat yang menurunkan $\mathrm{pH}$ juga dapat menghasilkan senyawa yang bersifat antibakteri seperti $\mathrm{H}_{2} \mathrm{O}_{2}$ dan bakteriosin. Rahayu et al. (2013) membuktikan bahwa sinbiotik bakteri $L$. fermentum 2B4 dengan fruktoolisakarida (FOS) selain bersifat antidiare juga bersifat antioksidatif. Nilai $\mathrm{pH}$ pada kontrol melebihi standar $\mathrm{pH}$ yogurt, sedangkan nilai $\mathrm{pH}$ pada susu fermentasi yang dibuat dengan penambahan TBN telah sesuai dengan standar.

\section{Mutu sensori minuman susu fermentasi}

Analisis sensori rating hedonik hanya dilakukan terhadap susu fermentasi yang ditambah tepung biji nangka (TBN) pada perlakuannya, sedangkan pada tiga perlakuan kontrol tidak dilakukan pengujian karena tidak memenuhi standar $\mathrm{pH}$. Hasil uji statistik (Tabel 2) terhadap tingkat kesukaan warna dan overall (keseluruhan) menunjukkan bahwa komposisi dengan TBN 4\% (b/v) dengan BAL L. brevis mendapat penilaian tingkat kesukaan tertinggi. Hasil analisis pada tingkat kesukaan aroma, rasa, dan tekstur, diketahui bahwa komposisi dengan $L$. plantarum dan $L$. brevis dengan TBN 5\% (b/v) memiliki tingkat kesukaan yang tertinggi, tetapi tidak berbeda nyata dengan komposisi $L$. brevis dengan TBN 4\% (b/v) yang memiliki skor tertinggi pada penilaian terhadap tingkat kesukaan warna dan overall (keseluruhan). Berdasarkan hasil analisis tersebut, maka formulasi yang dipilih untuk analisis selanjutnya adalah susu fermentasi dengan perlakuan penambahan TBN 4\% (b/v) dengan jenis BAL adalah L. brevis.

Skor kesukaan terhadap atribut warna dari perlakuan tersebut adalah 5,2 (agak disukai). Warna produk minuman susu fermentasi pada penelitian ini adalah putih kekuningan yang berasal dari susu segar dan TBN. Hasil penelitian ini dapat dibandingkan dengan penelitian Sulistyaning et al. (2020) yakni skor lebih tinggi diberikan kepada susu fermentasi dengan warna putih dan skor lebih rendah diberikan untuk warna tidak putih atau keruh. Warna perlu dianalisis tingkat kesukaan sensorinya karena warna merupakan atribut sensori yang pertama dilihat dalam memilih produk dan memengaruhi kesukaan konsumen.

Skor kesukaan terhadap atribut aroma dan rasa dari susu fermentasi tersebut adalah 4,6 (agak disukai) dan 4,2 (netral). Produk minuman susu fermentasi memiliki aroma dan rasa asam khas minuman susu fermentasi. Aroma dan rasa asam yang khas pada susu fermentasi disebabkan oleh adanya komponen asam laktat dan komponen flavor seperti diasetil, asetoin, dan asetaldehid yang diproduksi oleh kultur starter sebagai hasil fermentasi (Chen et al., 2017). Skor kesukaan terhadap atribut tekstur adalah 4.1 (netral). Produk minuman susu fermentasi berupa cairan dengan tekstur agak kental. Hal tersebut sesuai dengan SNI tentang susu fermentasi yang menyatakan penampakannya cair (BSN, 2009). Tekstur yang agak kental pada susu fermentasi dapat terbentuk karena adanya koagulasi protein susu. Skor kesukaan pada penilaian secara keseluruhan (overall) adalah 4,4 (netral).

Tabel 2. Skor mutu sensori minuman susu fermentasi

\begin{tabular}{|c|c|c|c|c|c|}
\hline BAL dan konsentrasi TBN & Warna & Aroma & Rasa & Tekstur & Overall \\
\hline L. plantarum, TBN 4\% (b/v) & $5,1 \pm 1,2^{\text {ab }}$ & $4,5 \pm 1,4^{\text {ab }}$ & $3,3 \pm 1,5^{b}$ & $3,5 \pm 1,4^{\text {cde }}$ & $3,7 \pm 1,3^{\mathrm{bc}}$ \\
\hline L. plantarum, TBN 5\% (b/v) & $4,5 \pm 1,1^{d}$ & $4,3 \pm 1,4^{\mathrm{ab}}$ & $3,1 \pm 1,5^{\mathrm{b}}$ & $2,8 \pm 1,3^{\dagger}$ & $3,4 \pm 1,2^{\mathrm{cd}}$ \\
\hline L. plantarum, TBN 6\% (b/v) & $4,4 \pm 1,2^{d}$ & $4,3 \pm 1,3^{\mathrm{ab}}$ & $3,2 \pm 1,4^{b}$ & $3,0 \pm 1,3^{\mathrm{et}}$ & $3,3 \pm 1,2^{d}$ \\
\hline L. brevis, TBN 4\% (b/v) & $5,2 \pm 1,0^{a}$ & $4,6 \pm 1,2^{a b}$ & $4,2 \pm 1,4^{a}$ & $4,1 \pm 1,2^{\mathrm{ab}}$ & $4,4 \pm 1,2^{\mathrm{a}}$ \\
\hline L. brevis, TBN 5\% (b/v) & $5,2 \pm 1,0^{a b}$ & $4,5 \pm 1,2^{a b}$ & $4,1 \pm 1,5^{\mathrm{a}}$ & $3,6 \pm 1,2^{\text {cd }}$ & $4,2 \pm 1,2^{\mathrm{a}}$ \\
\hline L. brevis, TBN 6\% (b/v) & $4,6 \pm 1,2^{\mathrm{cd}}$ & $4,1 \pm 1,2^{b}$ & $3,2 \pm 1,4^{b}$ & $3,2 \pm 1,3^{\text {det }}$ & $3,5 \pm 1,2^{\text {cd }}$ \\
\hline L. plantarum dan L. brevis, TBN 4\% (b/v) & $4,6 \pm 1,2^{\mathrm{cd}}$ & $4,4 \pm 1,2^{\mathrm{ab}}$ & $3,9 \pm 1,3^{a}$ & $3,5 \pm 1,3^{\mathrm{cd}}$ & $3,8 \pm 1,1^{\mathrm{bc}}$ \\
\hline L. plantarum dan L. brevis, TBN 5\% (b/v) & $4,8 \pm 1,1^{\mathrm{bcd}}$ & $4,7 \pm 1,0^{\mathrm{ab}}$ & $4,3 \pm 1,2^{\mathrm{a}}$ & $4,5 \pm 1,2^{\mathrm{a}}$ & $3,1 \pm 1,2^{\mathrm{ab}}$ \\
\hline L. plantarum dan L. brevis, TBN 6\% (b/v) & $5,0 \pm 1,1^{\mathrm{abc}}$ & $4,6 \pm 1,2^{a b}$ & $4,2 \pm 1,3^{a}$ & $3,9 \pm 1,5^{\mathrm{bc}}$ & $4,2 \pm 1,2^{\mathrm{a}}$ \\
\hline
\end{tabular}

Keterangan: ${ }^{2}$ Data yang diikuti huruf sama pada kolom sama tidak berbeda nyata pada uji Duncan taraf 0,05 
Mutu sensori minuman susu fermentasi yang terpilih tersebut adalah netral hingga agak disukai. Penelitian ini sejalan dengan penelitian Setiawan (2011) yang melakukan analisis sensori pada susu fermentasi plain dan susu fermentasi berperisa. Skor kesukaan dari pada susu fermentasi plain terhadap atribut warna, aroma, rasa, tekstur, dan overall (keseluruhan) adalah netral hingga agak disukai. Setelah dilakukan penambahan flavor (rasa) stroberi $1 \%(\mathrm{v} / \mathrm{v})$, mutu sensori meningkat menjadi agak disukai hingga suka. Hal ini menunjukkan bahwa pemberian flavor pada minuman susu fermentasi berpengaruh pada tingkat penerimaan produk.

Berdasarkan penilaian panelis pada uji sensori, urutan pengaruh atribut sensori pada minuman asam dari yang tertinggi hingga terendah adalah atribut rasa sebesar $33,81 \%$, aroma dan tekstur sebesar $25,53 \%$, dan warna sebesar $15,12 \%$. Selain penggunaan $L$. brevis dengan TBN 4\% (b/v) maka dari uji sensori ini juga dipilih formulasi penggunaan $L$. brevis dan $L$. plantarum dengan TBN $5 \%(b / v)$ yang memiliki skor tertinggi pada atribut rasa, aroma, dan tekstur untuk diuji lanjut. Hal tersebut dilakukan karena ingin mengetahui pengaruh adanya L. plantarum dan perbedaan TBN sebesar $1 \%(\mathrm{~b} / \mathrm{v})$ pada mutu kimia produk minuman susu fermentasi.

\section{Mutu kimia minuman susu fermentasi}

Hasil analisis kimia ke dua formulasi tersebut tertera pada Tabel 3. Hasil analisis statistik terhadap kadar air, lemak, protein, karbohidrat, dan keasaman menunjukkan tidak ada perbedaan nyata antara kedua formulasi, tetapi terdapat perbedaan nyata pada kadar abu. Hal ini sejalan dengan penelitian Afriani et al. (2011) yang menyatakan bahwa penggunaan kultur tunggal dan kombinasi tidak berpengaruh pada karakteristik kimiawi produk fermentasi.

Kadar abu yang lebih tinggi pada formulasi dengan penambahan tepung biji nangka (TBN) $5 \%$ (b/v) dapat disebabkan karena penambahan TBN yang mengandung serat pangan lebih tinggi dari pada formulasi dengan penambahan TBN 4\% (b/v). Pada saat fermentasi terbentuk gas yang akan menurunkan massa sehingga akan memperbesar nilai kadar abu produk (Johanningsmeier dan McFeeters, 2011). Susu fermentasi dengan penambahan TBN $5 \%(\mathrm{~b} / \mathrm{v})$ juga menggunakan dua jenis BAL yang diduga mampu membentuk gas dalam jumlah lebih banyak sehingga penurunan massa lebih besar dan nilai kadar abu juga menjadi lebih tinggi.

Minuman susu fermentasi dari kedua komposisi memiliki kadar air yang tinggi, yaitu $78,16 \%(\mathrm{~b} / \mathrm{b})$ pada susu fermentasi dengan TBN 4\% (b/v) dan $77,87 \%$ (b/b) pada susu fermentasi dengan TBN 5\% (b/v). Tingginya kadar air tersebut disebabkan susu segar yang digunakan sebagai bahan baku juga memiliki kadar air yang tinggi $(87,17 \%(b / b))$. Kadar abu kedua susu fermentasi tersebut melebihi standar SNI susu fermentasi yang menyatakan kadar abu maksimal sebesar 1,0\% (b/b) (BSN, 2009). Hal ini dapat disebabkan karena kedua komposisi tersebut dibuat dengan penambahan TBN yang memiliki kadar abu sebesar 2,24\% (b/b). Hasil serupa juga ditemui pada penelitian Amakoromo (2012) yang menunjukkan nilai kadar abu susu fermentasi yang ditambah kacang yam Afrika yaitu 1,20\% (b/b).

Kadar lemak mempengaruhi kekentalan susu fermentasi (Ciron et al., 2011). Kadar lemak kedua produk susu fermentasi tersebut memenuhi SNI susu fermentasi normal namun tidak memenuhi SNI untuk SNI susu fermentasi tanpa lemak. Kadar lemak produk hanya sekitar $50 \%$ dari kadar lemak bahan baku yang terdiri dari susu segar sebesar $5,16 \%(\mathrm{~b} / \mathrm{b})$ dan TBN sebesar $0,13 \%(\mathrm{~b} / \mathrm{b})$ untuk penambahan TBN $4 \%(\mathrm{~b} / \mathrm{v})$ dan $0,16 \%(\mathrm{~b} / \mathrm{b})$ untuk penambahan TBN 5\% (b/v). Reduksi lemak terjadi karena BAL memiliki aktivitas lipolitik yang mengubah lemak menjadi asam lemak dan gliserol. BAL heterofermentatif, termasuk $L$. brevis, menggunakan gliserol sebagai penerima elektron dalam kofermentasi dengan glukosa. Adanya gliserol juga mampu menstimulasi pertumbuhan BAL heterofermentatif (Vieira et al., 2015) karena lemak digunakan sebagai sumber energi untuk pertumbuhan bakteri.

Tabel 3. Kadar proximat dan asam laktat minuman susu fermentasi

\begin{tabular}{|c|c|c|c|}
\hline \multirow[b]{2}{*}{$\begin{array}{c}\text { Karakteristik } \\
\text { Kimia }\end{array}$} & \multicolumn{3}{|c|}{ Kandungan \% (b/b) } \\
\hline & $\begin{array}{c}\text { Komposisi } \\
\text { A }\end{array}$ & $\begin{array}{c}\text { Komposisi } \\
\text { B }\end{array}$ & $\begin{array}{l}\text { SNI (BSN, } \\
2009)\end{array}$ \\
\hline Kadar air & $78,16 \pm 1,48^{a}$ & $77,87 \pm 1,77^{\mathrm{a}}$ & - \\
\hline Kadar abu & $2,34 \pm 0,07^{\mathrm{a}}$ & $4,29 \pm 0,29^{b}$ & maks 1,0 \\
\hline Kadar & $2,85 \pm 0,75^{\mathrm{a}}$ & $2,88 \pm 0,85^{\mathrm{a}}$ & $\min 0,6$ \\
\hline lemak & & & $\begin{array}{c}\text { maks 0,5 } \\
\text { (tanpa } \\
\text { lemak) }\end{array}$ \\
\hline $\begin{array}{l}\text { Kadar } \\
\text { protein }\end{array}$ & $3,15 \pm 0,56^{a}$ & $1,88 \pm 0,66^{a}$ & $\min 1,0$ \\
\hline $\begin{array}{l}\text { Kadar } \\
\text { karbohidrat }\end{array}$ & $13,51 \pm 0,10^{a}$ & $13,08 \pm 2,25^{\mathrm{a}}$ & - \\
\hline Asam laktat & $1,85 \pm 0,03^{a}$ & $1,99 \pm 0,17^{\mathrm{a}}$ & $0,2-0,9$ \\
\hline
\end{tabular}

Keterangan: Komposisi $\mathrm{A}=$ L. brevis, TBN $4 \%(\mathrm{~b} / \mathrm{v})$; Komposisi $\mathrm{B}=$ L. plantarum dan L. brevis, TBN $5 \%$ $(\mathrm{b} / \mathrm{v}) ;^{*}=$ Dihitung berdasarkan basis basah; ${ }^{\mathrm{a}, \mathrm{b}}$ Data yang diikuti huruf sama pada baris sama tidak berbeda nyata pada uji Duncan taraf 0,05

Kandungan protein merupakan salah satu faktor penting pada susu fermentasi karena berperan dalam pembentukan kekentalan (Delikanli dan Ozcan, 2017). Kadar protein susu fermentasi dengan TBN 4 dan $5 \%(b / v)$ telah sesuai dengan SNI tentang syarat mutu susu fermentasi, yaitu minimal $1.0 \%$ (b/b) untuk protein (BSN, 2009). Kandungan protein susu fermentasi dengan TBN $5 \%$ (b/v) lebih kecil daripada susu fermentasi dengan TBN 4\% 
(b/v). Susu fermentasi dengan TBN 4\% (b/v) memiliki penurunan kadar protein menjadi 3,15\% (b/b) jika dibandingkan kadar protein bahan baku susu segar sebesar 3,03\% (b/b) dan TBN sebesar 0,50\% (b/b). Susu fermentasi dengan TBN 5\% b/v) juga memiliki penurunan kadar protein menjadi $1,88 \%$ (b/b) jika dibandingkan kadar protein bahan baku susu segar sebesar 3,03\% (b/b) dan TBN sebesar 0,63\% (b/b). L. plantarum adalah BAL yang mengandung semua gen yang dibutuhkan untuk mendegradasi protein secara intraseluler. Hal tersebut mengindikasikan bahwa degradasi protein menjadi asam amino pada susu fermentasi yang menggunakan $L$. brevis dan $L$. plantarum berlangsung lebih optimal, artinya asam amino yang terbentuk lebih banyak daripada yang hanya menggunakan L. brevis. Penurunan kadar protein susu asam yang menggunakan campuran $L$. plantarum dan $L$. brevis lebih besar daripada hanya menggunakan $L$. brevis. Hal ini terjadi karena kultur campuran dari 2 bakteri (L. plantarum dan L. brevis) membutuhkan energi yang lebih banyak daripada kultur tunggal (L. brevis) karena asam amino hasil pemecahan protein merupakan sumber nitrogen utama yang dimanfaatkan sebagai sumber energi oleh mikroba.

Asam laktat pada susu fermentasi merupakan hasil fermentasi BAL baik $L$. plantarum maupun $L$. brevis. Asam laktat berperan dalam pembentukan aroma, rasa, dan tekstur serta menghambat pertumbuhan mikroba patogen (Rattanachaikunsopon dan Phumkhachorn, 2010). Asam laktat yang dihasilkan dari kedua formulasi tersebut lebih besar dari pada yang dipersyaratkan $\mathrm{SNI}$ tentang syarat mutu susu fermentasi yaitu $0,2-0,9 \%$ (b/b) dan syarat mutu yogurt yaitu $0,5-2,0 \%$.

\section{KESIMPULAN}

Pembuatan minuman susu fermentasi yang direkomendasikan adalah dengan melakukan penambahan tepung biji nangka (TBN) sebanyak $4 \%$ $(\mathrm{b} / \mathrm{v})$ menggunakan BAL L. brevis karena memberikan nilai mutu sensori dari netral hingga agak disukai pada atribut warna, aroma, rasa, tekstur, dan overall. Penambahan TBN pada susu sebagai bahan dasar susu fermentasi mampu meningkatkan jumlah BAL sebanyak satu log, sehingga berpotensi sebagai prebiotik. Susu fermentasi yang dihasilkan memiliki kadar lemak dan protein yang memenuhi SNI tentang syarat mutu susu fermentasi, sedangkan kadar abunya melebihi yang dipersyaratkan.

\section{DAFTAR PUSTAKA}

Afriani, Suryono, Lukman H. 2011. Karakteristik dadih susu sapi hasil fermentasi beberapa starter bakteri asam laktat yang diisolasi dari dadih asal kabupaten Kerinci. Agrinak 1: 36-42.

Amakoromo ER, Innocent AHC, Njoku HO. 2012. Shelf-life study of yoghurt-like product from African yam bean. Nat Sci 10: 58-63.

Andarwulan N, Kusnandar F, Herawati D. 2011. Analisis Pangan. 142. Dian Rakyat, Jakarta.

[AOAC] Association of Official Analytical Chemists. 2000. Official Methods of Analysis. AOAC, Washington.

Aswal P, Shukla A, Priyadarshi S. 2013. Yoghurt: Preparation, characteristics and recent advancements. Cibtech-J Bio-Protocols 1: 32-44.

[BAM] Bacteriological Analytical Manual. 2001. Aerobic Plate Count. FDA, US.

[BSN] Badan Standardisasi Nasional. 2009. Syarat Mutu Yoghurt. Badan Standardisasi Nasional, Jakarta.

[BSN] Badan Standardisasi Nasional. 2009. Syarat Mutu Minuman Susu Fermentasi Berperisa. Badan Standardisasi Nasional, Jakarta.

Caleja C, Barros L, Antonio AL, Carocho M, Oliveira MBP, Ferreira IC. 2016. Fortification of yogurts with different antioxidant preservatives: A comparative study between natural and synthetic additives. Food Chem 210: 262-268. DOI: 10. 1016/j.foodchem.2016.04.114.

Chen C, Zhao S, Hao G, Yu H, Tian H, Zhao G. 2017. Role of lactic acid bacteria on the yogurt flavour-a review. Int J Food Prop 20: S316S330. DOI: 10.1080/10942912.2017.1295988.

Chowdhury AR, Bhattacharyya AK, Chattopadhyay. 2012. Study on functional properties of raw and blended jackfruit seed flour (a non-conventional source) for food application. J Nat Prod Resour 3: 347-353.

Ciron CIE, Gee VL, Kelly AL, Auty MA. 2011. Effect of microfluidization of heat-treated milk on rheology and sensory properties of reduced fat yoghurt. Food Hydrocolloid 25: 1470-1476. DOI: 10.1016/j.foodhyd.2011.02.012.

Das A, Raychaudhuri U, Chakraborty R. 2012. Cereal based functional food of Indian subcontinent-a review. J Food Sci Technol 49: 665672. DOI: 10.1007/s13197-011-0474-1. 
Delikanli B, Ozcan T. 2017. Improving the textural properties of yogurt fortified with milk proteins. $J$ Food Process Pres 41: e13101. DOI: 10.1111/ jfpp. 13101.

Gibson GR, Hutkins R, Sanders ME, Prescott SL, Reimer RA, Salminen SJ, Scott K, Stanton C, Swanson KS, Cani PD, Verbeke K, Reid G. 2017. Expert consensus document: The international scientific association for probiotics and prebiotics (ISAPP) consensus statement on the definition and scope of prebiotics. Nat Rev Gastroentero 14: 491-502. DOI: $10.1038 / \mathrm{nr}$ gastro.2017.75.

Hill C, Guarner F, Reid G, Gibson GR, Merenstein DJ, Pot B, Morelli L, Canani RB, Flint HJ, Salminen S, Calder PC, Sanders ME. 2014. The International Scientific Association for Probiotics and Prebiotics consensus statement on the scope and appropriate use of the term probiotic. Nat Rev Gastroentero 11: 506-514. DOI: 10.1038/nrgastro.2014.66.

Hooper LV, Littman DR, Macpherson AJ. 2012. Interactions between the microbiota and the immune system. Science 336: 1268-1273. DOI: 10.1126/science.1223490.

Johanningsmeier SD, McFeeters RF. 2011. Detection of volatile spoilage metabolites in fermented cucumbers using nontargeted, comprehensive 2-dimensional gas chromatographytime-of-flight mass spectrometry $(\mathrm{GC} \times \mathrm{GC}$ TOFMS). J Food Sci 76: 168-177. DOI: 10.111 1/j.1750-3841.2010.01918.x.

Kementerian Kesehatan Republik Indonesia. 2018. Profil Kesehatan Indonesia Tahun 2017. Kementerian Kesehatan RI, Jakarta.

Lee WJ, Lucey JA. 2010. Formation and physical properties of yoghurt. Asian-Australasia J Anim Sci 23: 1127-1136. DOI: 10.5713/ajas.2010. r.05.

Lee B, Yong C-C, Yi H-C, Kim S, Oh S. 2020. A non-yeast kefir-like fermented milk development with Lactobacillus acidophilus KCNU and Lactobacillus brevis Bmb6. Food Sci Anim Resour 40: 541-550. DOI: 10.5851/kosfa.2020.e31.

Martinez FD. 2014. The human microbiome. Early life determinant of health outcomes. Ann Am Thorac Soc 11: 7-12. DOI: 10.1513/AnnalsATS. 201306-186MG.

Matjik AA, Sumartajaya IM. 2011. Sidik Peubah Ganda dengan Menggunakan SAS. 77. IPB Press, Bogor.

Pathak M, Martirosyan D. 2012. Optimization of an effective growth medium for culturing probiotic bacteria for applications in strict vegetarian food products. Funct Food Health Dis 2: 369-378. DOI: 10.31989/ffhd.v2i10.75.

Prückler M, Lorenz C, Endo A, Kraler M, Dürrschmid K, Hendriks K, da Silva FS, Auterith E, Kneifel W, Michlmayr H. 2015. Comparison of homoand heterofermentative lactic acid bacteria for implementation of fermented wheat bran in bread. Food Microbiol 49: 211-219. DOI: 10.10 16/j.fm.2015.02.014.

Quigley EMM. 2019. Prebiotics and probiotics in digestive health. Clin Gastroenterol H 17: 333344. DOI: 10.1016/j.cgh.2018.09.028.

Rahayu WP, Kusnandar F, Prayitno WA. 2011. Stability of viable counts of lactic acid bacteria during storage of goat milk soft cheese. Microbiol Indonesia 5: 149-153. DOI: 10.5454/mi.5.4.1.

Rahayu WP, Astawan M, Wresdiyati T, Mariska S. 2013. Antidiarrheal and antioxidative capability of synbiotic yogurt to the rats. Int Food Res $\mathrm{J}$ 20: 653-659.

Ramos CL, Thorsen L, Schwan RF, Jespersen L. 2013. Strain-specific probiotics properties of Lactobacillus fermentum, Lactobacillus plantarum and Lactobacillus brevis isolates from Brazilian food products. Food Microbiol 36: 2229. DOI: 10.1016/j.fm.2013.03.010.

Rattanachaikunsopon P, Phumkhachorn P. 2010. Lactic acid bacteria: their antimicrobial compounds and their uses in food production. Annals Biol Res 1: 218-228.

Setyawardani T, Rahayu WP, Maheswari R, Palupi NS. 2011. Identification and characterization of probiotic lactic acid bacteria isolated from indigenous goat milk. Anim Production 13: 57-63.

Setyawardani T, Rahayu WP, Maheswari RR, Palupi NS. 2014. Antimicrobial activity and adhesion ability of indigenous lactic acid bacteria isolated from goat milk. Int Food Res J 1: 959-964.

Setyawardani T, Rahayu WP, Palupi NS, Sumarmono J. 2017. The potential of Lactobacillus rhamnosus and Lactobacillus plantarum isolated from goat's milk in inhibiting Salmonella typhimurium ATCC 14028 infections in rats. Int Food Res J 24: 2625-2631.

Shen X, Yi D, Ni X, Zeng D, Jing B, Lei M, Bian Z, Zeng Y, Li T, Xin J. 2014. Effects of Lactobacillus plantarum on production performance, immune characteristics, antioxidant status, and intestinal microflora of bursin-immunized broilers. Can J Microbiol 60: 193-202. DOI: 10. 1139/cjm-2013-0680. 
Sulistyaning AR, Putri WAK, Winarsi H, Fitri A. 2020. Yogurt kacang merah plus susu kambing sebagai snack sehat tinggi zat besi bagi remaja anemia. Gizi Indonesia 43: 25-36. DOI: 10.364 57/gizindo.v43i1.468.

Talpur AD, Ikhwanuddin M, Abdullah MDD, Bolong AMA. 2013. Indigenous Lactobacillus plantarum as probiotic for larviculture of blue swimming crab, Portunus pelagicus (Linnaeus, 1758): Effects on survival, digestive enzyme activities and water quality. Aquaculture 416-417: 173178. DOI: 10.1016/j.aquaculture.2013.09.018.

Verbeke KA, Boobis AR, Chiodini A, Edwards CA, Franck $A$, Kleerebezem M, Nauta A, Raes J, van Tol EFA, Tuohy KM. 2015. Towards microbial fermentation metabolites as markers for health benefits of prebiotics. Nutr Res Rev 28: 42-66. DOI: 10.1017/S0954422415000037.

Vieira PB, Kilikian BV, Bastos RV, Perpetuo EA, Nascimento CAO. 2015. Process strategies for enhanced production of 1, 3-propanediol by Lactobacillus reuteri using glycerol as a cosubstrate. Biochem Eng J 94: 30-38. DOI: 10. 1016/j.bej.2014.11.003.

[WHO/FAO] World Health Organization \& Food and Agriculture Organization. 2006. Probiotic in Food. Health and Nutrition Properties and Guidelines for Evaluation. FAO Food and Nutrition Paper 85. Rome Italy.

Wichienchot $S$, Thammarutwasik $P$, Jongjareonnrak A, Chansuwan W, Hmadhlu P, Hongpattarakere T, Itharat A, Ooraikul B. 2011. Extraction and analysis of prebiotics from selected plants from southern Thailand. Songklanakarin J Sci Technol 33: 517-523.

Yakabe T, Moore EL, Yokota S, Sui H, Nobuta Y, Fukao M, Palmer H, Yajima N. 2009. Safety assessment of Lactobacillus brevis KB290 as a probiotic strain. Food Chem Toxicol 47: 24502453. DOI: 10.1016/j.fct.2009.07.001. 